\title{
Innovation and Archive Management in Improving the Performance of the Probolinggo City DPRD
}

\author{
Dwi Putranto Riau', Ridho Harta ${ }^{2}$, Ricky Patra Hakim ${ }^{3}$ \\ ${ }^{1}$ Lecture of Public Administration Department Faculty of Law, Social and Political Sciences \\ Universitas Terbuka (email: dwiputranto@ecampus.ut.ac.id) \\ ${ }^{2}$ Head of Public Administration Department Faculty of Law, Social and Political Sciences \\ Universitas Terbuka (email: ridho@ecampus.ut.ac.id) \\ ${ }^{3}$ Archive program study Student Universita Terbuka (email: patrahakim@gmail.com)
}

\begin{abstract}
The current condition of the COVID-19 pandemic has made government offices implement work from home this has resulted in a large number of official archives, , especially the letter of responsibility (SPJ) for official travel and the letters that come in every day make the archives pile up and also the archives that do not fit to accommodate the archives, the implementation of activities that are hampered because the disposition letter of the leadership has not been dropped and the use of Simaya's correspondence application by The leadership of the DPRD and the DPRD Secretariat who have not been integrated into accelerating the disposition of program implementation policies. This makes SKPD leaders need a strategy to reduce the archives that keep coming and integrate programs and activities. One of the strategies is to digitize archives.

This study uses a qualitative method by conducting interviews with related actors, namely archivist functional officers and structural officials as well as secondary data staff.

The results of the study show that innovation and archive management, one of which is archive digitization, can reduce the place to accommodate archives, work faster in data access, and can support improving the performance of the Probolinggo City DPRD.
\end{abstract}

\section{Keywords:}

innovation; management; digitizing; data; archives

\section{Introduction}

Many archives that accumulate need to be managed archives so that archives as agency assets are managed effectively and efficiently based on related information. Many archives exist and enter the database, so information is increasingly difficult to monitor. Information management plays a role in arranging information to be recorded and recorded into reports that facilitate the information needed. One source of data is archived. Archives are evidence and records of activities or all activities ranging from service activities at the counter for technical service SKPD or Public Service Malls. Archives can be processed 
manually or electronically into information that can be used as a basis for decision-making by agency leaders.

Management or archive management encountered obstacles in the agency, one of which was the activities of the SKDP Leader attending ceremonial events and official trips for the DPRD leadership, both the Secretary of the Council and the DPRD Leader, making the policy of disposition of letters hampered and stopped at the leadership desk, many letters and activities which cannot be directly implemented by staff.

The role of archives as a "memory center" source of information and as a tool "as an indispensable tool in every organization in the context of activities" planning, analyzing, developing, formulating policies, decision making, reporting, accountability, assessment, and control as appropriate. (Mas, 2014)

Archives play a very important role in the process of presenting information for leaders to make decisions and formulate policies. To be able to produce fast and credible information, systems and work procedures are needed in archive management. Also the process of digitizing archives, namely the process of converting media/information that is printed, written, and/or drawn into digital form or format.(Digitaslisasi Arsip Statis, 2020) While the purpose of digitizing archives is so that archives or recorded information can be accessed through computer systems (online, offline, anytime and anywhere); One of today's archive preservation strategies is to keep abreast of technological developments and so that archives can be maintained and maintained in local repositories or cloud storage.

The role of archives is very important in presenting information for organizations in making decisions for leaders, so archives need to be managed by procedures agreed upon by the organizational team in achieving the vision and mission. For this reason, good records management is needed so that the presentation of transparent and credible data can be accounted for. Archival management or archive management needs to be managed specifically so that archives can be maintained properly. By following the times and technology, archives are managed with information technology or digitization so that it does not need a place that takes up a large space.

Fast and credible information in archive management is the digital application of letters, namely Si Maya, which has been implemented within the Probolinggo City Government. At the DPRD Probolinggo Simaya, it was only implemented by the leadership 
of the DPRD Secretariat but at the DPRD leadership level there was still no manual, only through letters and disposition decisions waiting for the leadership's policy, in the end, many activities were waiting.

The problem with archives in the Probolinggo City DPRD is the number of archives that enter into archive management/management tasks, the implementation of activities that are hampered because of the leadership disposition letter that has not come down due to the DPRD leadership busy carrying out routine tasks and the use of Simaya correspondence applications by the DPRD leadership and DPRD Secretariat who have not integrated into accelerating the disposition of letters into the DPRD leadership strategy in improving DPRD performance.

Formulation of the problem

Existing problems based on the description above can be put forward research questions as follows:

- What is the strategy of the DPRD leadership in managing records to improve organizational performance?

\section{Research Objectives}

By the formulation of the problem above, the objectives of this study are:

- Review and analyze records management in improving performance to achieve organizational goals

2. Research Benefits.

The benefits of this research are as follows:

a. This research is expected to contribute ideas on archive management for the development of public administration and improving organizational performance

b. This research is expected to add academic insight and horizons of thought as well as valuable experience for researchers.

\section{Methods}

The method used in this research is descriptive qualitative/quasi-qualitative. (Bungin, 2017).The qualitative descriptive method is a research method that aims to make a systematic, factual, and accurate description of a social phenomenon or natural phenomenon. Data that is in the form of words and not a series of numbers is obtained in various ways, namely 
observation, interviews, document digests, or in other ways that are usually processed first before they are ready to be used, but the qualitative analysis still uses words, which are usually compiled into text that is expanded. (Moleong, 2006)(Miles, 1992: 15-16). The study of primary data through data collection techniques with in-depth interviews (In-depth Interviews) and secondary data studies through data collection at the secretariat of the DPRD Probolinggo City.

The data analysis technique used in this research is descriptive research as proposed by Sugiyono (2003) where the aim is to analyze the data by describing or describing the data that has been collected as it is without using the analysis that is usually put forward based on statistical analysis techniques (Rachman, 2018)

The phenomenon to be studied is the problem of archive management in improving the performance of the Probolinggo City DPRD. The phenomena of filing problems at the DPRD secretariat will be described in a systematic, factual, and accurate manner.

\section{Result and Discussion}

The number of archives in the DPRD Secretariat during 2020 and 2021 is 3867 letters and from 2021 to August 2021 as many as 2565 with information on security classifications and closed archive access with details as shown in Table 1 below:

Table 1.

Number of incoming letters

\begin{tabular}{llll}
\hline No & Tahun & Jumlah Surat & $\begin{array}{c}\text { Ket. Klasifikasi } \\
\text { Keamanan dan Akses Arsip }\end{array}$ \\
\hline 1 & 2020 & 3867 & Tertutup \\
2 & 2021 (s/d agustus) & 2565 & Tertutup \\
\hline
\end{tabular}

Source: Probolinggo City DPRD Secretariat 2021 
Table 2

\section{Contents of Active Files of the Probolinggo City DPRD Secretariat 2020}

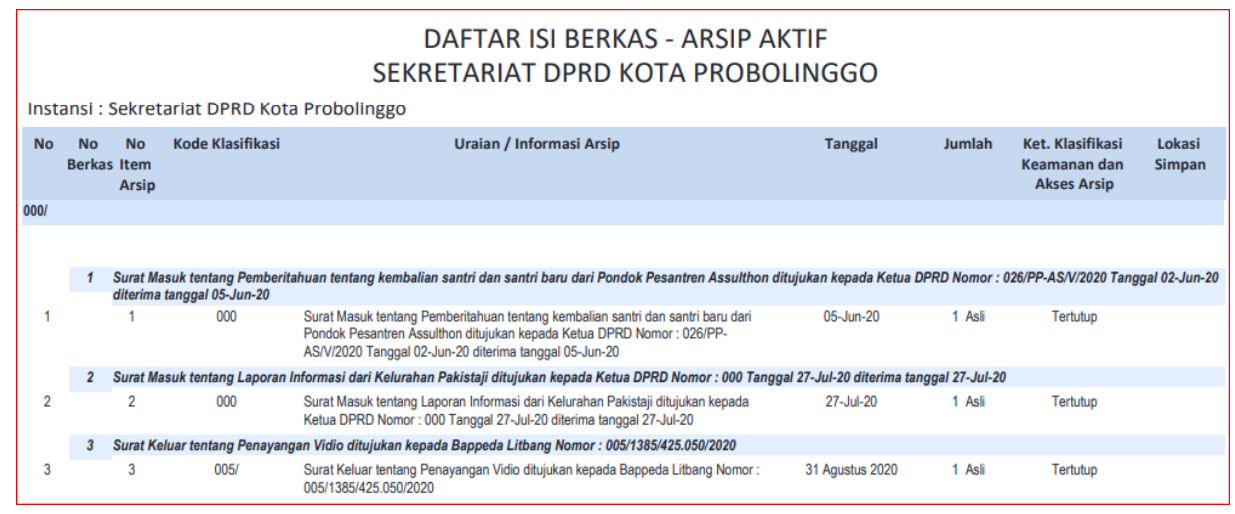

Source: Probolinggo City DPRD Secretariat 2021

In the archive format at the Probolinggo City DPRD Secretariat in 2020, the archive arrangement is still not standardized(Dev \& Patgiri, 2015), Table 2 contains no, no file, no archive item, these three numbers into one should be arranged just one number consisting of file number and archive item number. classification code, description/archive information, date, number, description of security classification, and access to archives as well as the location where they are stored are not stored. The number of archives in 2020 is said to be 3867 while in 2021 there is no letter-number so you have to manually calculate the number of letters in 2021.Table 1 Number of incoming letters.

Table 3.

\section{Contents of Active Files of the Probolinggo City DPRD Secretariat 2021}

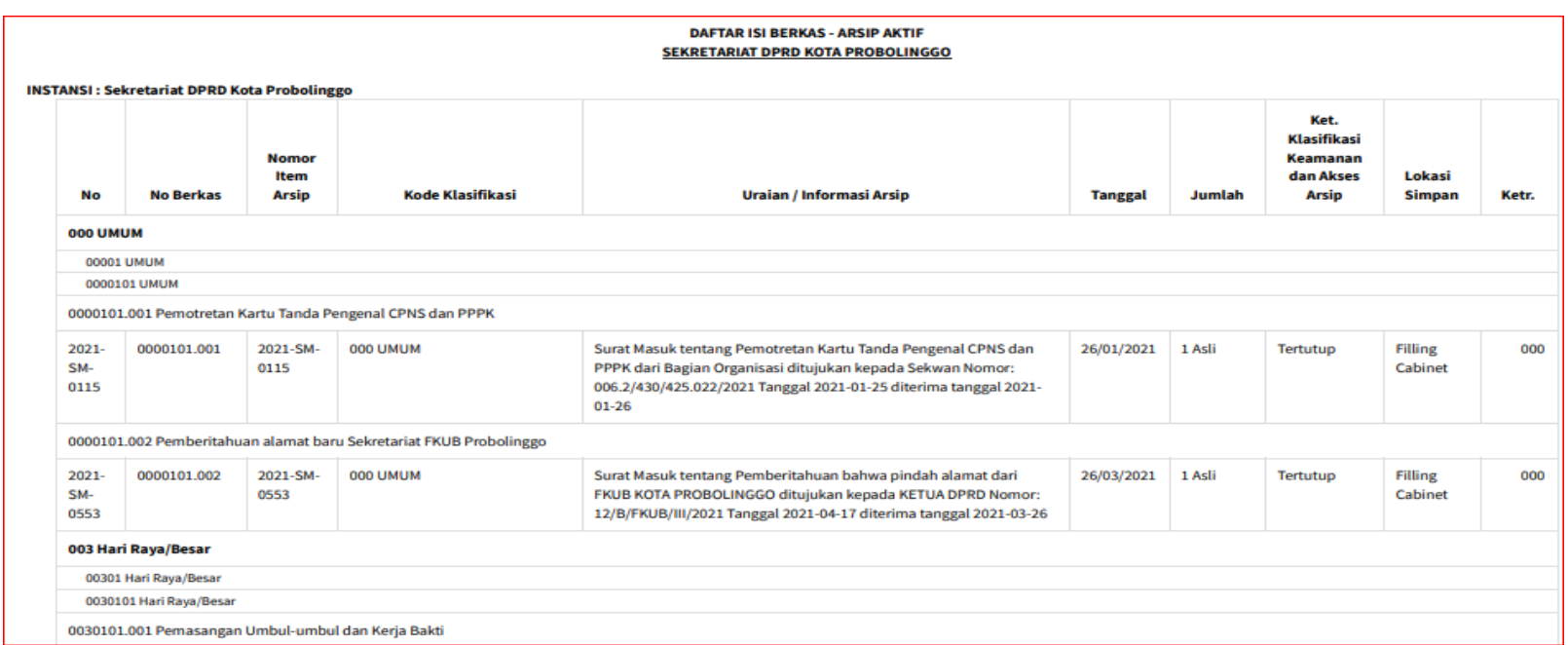

Source: Probolinggo City DPRD Secretariat 2021

The Archive Administration Arrangement in 2021 is neat and by archival procedures by filling in the table columns according to the fields as shown in Table 3 above. 
The administration of the DPRD secretariat regarding letter registration has used the Si Maya application, but its use is still limited to registration of incoming letters, while registration of outgoing letters is still manually using paper, this is due to the quantity of incoming and outgoing letters that must be registered quickly so that it will be more effective if it is carried out by 2 (two) people, namely 1 (one) person registering incoming mail using the application and 1 (one) other person registering outgoing mail manually. However, over time, the use of manual methods in registering outgoing mail was deemed less than optimal when searching for outgoing mail. Apart from that, they also have difficulty when doing Correspondence Archives. (Judge Ricky Patria, 2021)

Requests for archive registration services and information on activity schedules outside of working hours and days, in the Simaya application, there is no registration/letter numbering feature. From these problems, the Probolinggo City DPRD Secretariat needs an application that can be used by more than 1 (one) person simultaneously and reduces human error when numbering letters. The archive management application is very necessary for carrying out archive management so that it remains

The schedule of the work plan of the leadership and members of the DPRD which is dense with programs and activities according to Table 4 for a year shows that a reference study plan needs to be carried out on a planned schedule and communicated with the local government in carrying out activities according to the rules, especially the RAPERDA APBD which already has regulations from the Ministry of Home Affairs. and the Ministry of Finance regarding the fulfillment of the target for the completion of the APBD. The schedule of the agenda plan may change due to refusing or budget reductions in the APBD changes for handling the covid-19 pandemic.(Ridho, 2021)

The activities of the DPRD leadership and members, as well as the DPRD Secretariat, affect the activities of implementing office administration, especially the disposition of pending letters from the leadership.

\section{Table 4.}

Agenda for the Work Plan of Probolinggo City Leaders and Members of DPRD

\begin{tabular}{lll}
\hline No & Programs and Activities & Schedule planning \\
\hline I & Regional Representative Institution Capacity Building Program & \\
1 & Discussion of Draft Regional Regulations & \\
1.1 & Discussion of the Regional Budget Draft &
\end{tabular}




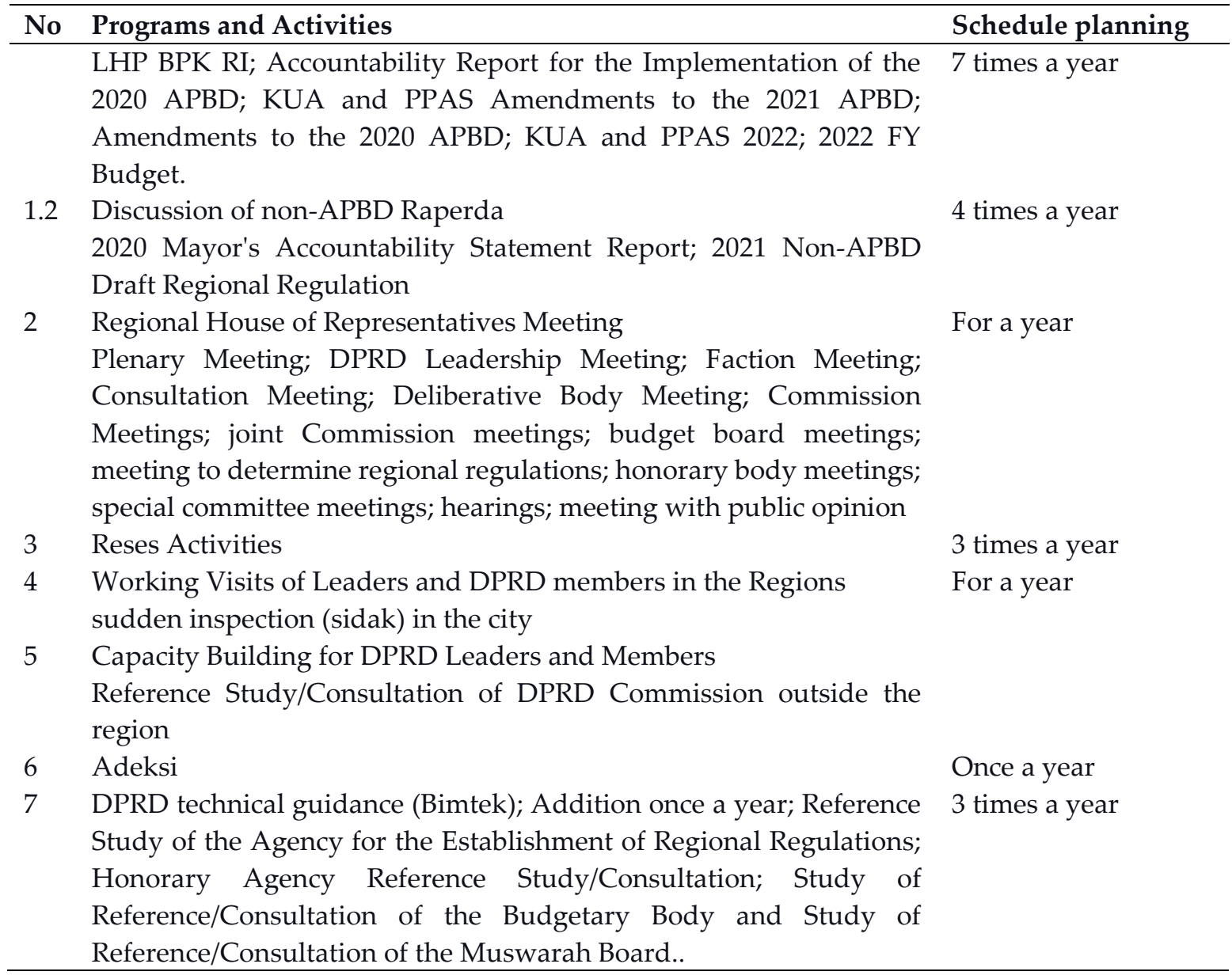
Source: Probolinggo City DPRD Secretariat 2021

From the problems discussed above, several innovation strategies and archive management at the Probolinggo City DPRD secretariat can be taken, namely:

1. It is necessary to plan the digitization of static archives so that archives can be maintained and maintained in local repositories or cloud storage, long-term and high resolution plans in storage and archive maintenance/preservation; maintain the security, safety \& integrity of the transferred archives(Diamond et al., 2003).

2. Implementing the standard operating procedure (SOP) for digitization: 1. Preparation (PreDigitization) 2. Implementation/Process 3. Verification / QC 4. Making Minutes 5. Authentication

3. Increasing the competence of Human Resources or archiving officers in archive management through increasing knowledge, skills and motivation. Knowledge through improving education, skill refers to the ability to do work through training and motivation is encouragement and enthusiasm to do work through improving work culture.

4. Improvement of archival facilities and infrastructure through filing cabinets 
5. Increasing the archive budget every year

6. Create a Web-Based Archive Management/Management Application to support the main tasks and functions of the Probolinggo City DPRD Secretariat by accelerating the process of letter registration and filing of incoming and outgoing mail and integrated with existing applications such as the Si Maya application.

7. Preparation of Leadership Policy in the form of a Decree on the management of archives within the DPRD based on a management information system (SIM) as a legal umbrella so that archive management can be managed and implemented according to the development of information technology that supports the development of e-government Government.

\section{Conclusion}

From the results and discussion above, conclusions can be drawn:

1. Archives as memories and memories, material for consideration and decision making, as legal support or evidence if needed and as historical references.

2. It is necessary to plan digitalization of static archives so that archives can be maintained and maintained, long-term plans and high resolution in storage and maintenance / preservation of archives; maintain security, safety \& integrity of the transferred archives and implement standard operating procedures in digitizing archives.

3. Increasing organizational resources through increasing human resource competencies, increasing archival facilities and infrastructure and increasing archive budgets every year.

4. Create an Archives Management. Application that is integrated with other administrative applications.

5. Drafting of the Decree of the Secretary of the DPRD regarding the Management of Archives within the DPRD based on the Management Information System (SIM) as a legal umbrella for the implementation of archive management.

\section{References}

An, X., Bai, W., Deng, H., Sun, S., Zhong, W., \& Dong, Y. (2017). A knowledge management framework for effective integration of national archives resources in China. Journal of Documentation, 73(1), 18-34. https://doi.org/10.1108/JD-04-2016-0040

Bungin, H. M. B. (2017). Penelitian Kualitatif. Komunikasi, Ekonomi, Kebijakan Publik, dan Ilmu 
Sosial Lainnya. (Kedua). KENCANA.

Dev, D., \& Patgiri, R. (2015). HAR+: Archive and metadata distribution! Why not both? 2015 International Conference on Computer Communication and Informatics, ICCCI 2015, June 2015. https://doi.org/10.1109/ICCCI.2015.7218119

Diamond, H. J., Bates, J. J., Clark, D. M., \& Mairs, R. L. (2003). Archive management: The missing component. Proceedings - 20th IEEE/11th NASA Goddard Conference on Mass Storage Systems and Technologies, MSST 2003, 40-48. https://doi.org/10.1109/MASS.2003.1194834

Farida, I. (2020). the Influence of Employee Participation on Archive Management in the City of Bandar Lampung. Sosiohumaniora, 22(2), 140-145. https://doi.org/10.24198/sosiohumaniora.v22i2.24988

Fathurrahman, M. (2018). PENTINGNYA ARSIP SEBAGAI SUMBER INFORMASI Muslih Fathurrahman. Jurnal Ilmu Perpustakaan Dan Informasi, 3(2), 215-225.

Kriswanto Remetwa, M. G., Ardianto, Y. T., \& Sisharini, N. (2018). Analisis Strategi dan Sistem Informasi Manajemen dengan Menggunakan Strengths, Weaknesses, Opportunities, Threats (SWOT) Pada Kantor Pos Malang 65100. Jurnal Riset Inspirasi Manajemen Dan Kewirausahaan, 2(1), 38-45. https://doi.org/10.35130/jrimk.v2i1.34

Mas, H. (2014). Adminsitrasi Perkantoran (Enceng (ed.); Cetakan Pe).

Moleong, R. J. (2006). Metodologi Penelitian Kualitatif. Rosda.

Digitaslisasi Arsip Statis, (2020).

Patil, M. B. (2020). Improved performance in multi-objective optimization using external archive. Sadhana - Academy Proceedings in Engineering Sciences, 45(1). https://doi.org/10.1007/s12046-020-1309-4

Pertiwi, H., \& Ranu, M. E. (2014). Keefektifan sistem informasi manajemen kearsian (semar) terhadap penemuan kembali arsip di kantor perpustakaan dan kearsipan kabupaten Sidoarjo. Journal Informatika, 1-17.

Ridho, R. D. P. and H. (2021). The schedule of the work plan of the leadership and members of the DPRD which is dense with programs and activities according to Table 5 for a year shows that a reference study plan needs to be carried out on a planned schedule and communicated with the 1. ICOGPASS LAN RI.

Rumere, H. M., Tanaamah, A. R., \& Sitokdana, M. N. N. (2020). Analisis Kinerja Tata Kelola 
Teknologi Informasi Pada Dinas Perpustakaan Dan Kearsipan Daerah Kota Salatiga Menggunakan Framework Cobit 5.0. Sebatik, 24(1), 14-21. https://doi.org/10.46984/sebatik.v24i1.926

Zulhalim. (2019). Pengembangan Sistem Informasi Manajemen Arsip Statis (SIMARS-PLUS) Berbasis Web dengan Pendekatan Extreme Programming pada Dinas Perpustakaan dan Kearsipan Provinsi DKI Jakarta Tahun Anggaran 2018. Journal of Information System, Informatics and Computing (JISICOM), 3(2), 64-78. http://journal.stmikjayakarta.ac.id/index.php/jisicom/article/view/141/122 